\section{Evaluating Hybrid Bermudagrass Using Spectral Reflectance under Different Mowing Heights and Trinexapac-ethyl Applications}

\author{
Dana Sullivan ${ }^{1}$, Jing Zhang ${ }^{2,7}$, Alexander R. Kowalewski ${ }^{3}$, \\ Jason B. Peake ${ }^{4}$, William F. Anderson ${ }^{5}$, F. Clint Waltz Jr. ${ }^{6}$, and \\ Brian M. Schwartz ${ }^{2}$
}

AdDitional INDEX wORDs. normalized difference vegetation index, ratio vegetation index, turfgrass quality, percent green cover, surface firmness

Summary. Quantitative spectral reflectance data have the potential to improve the evaluation of turfgrasses in variety trials when management practices are factors in the testing of turf aesthetics and functionality. However, the practical application of this methodology has not been well developed. The objectives of this research were 1) to establish a relationship between spectral reflectance and turfgrass quality (TQ) and percent green cover (PGC) using selected reference plots; 2 ) to compare aesthetic performance (TQ, PGC, and vegetation indices) and functional performance (surface firmness); and 3 ) to evaluate lignin content as an alternate means to predict surface firmness in turfgrass variety trials of hybrid bermudagrass [Cynodon dactylon $\times$ C. transvaalensis]. A field study was conducted on mature stands of three varieties ('TifTuf', 'TifSport', and 'Tifway') and two experimental lines (04-47 and 04-76) at two mowing heights (0.5 and $1.5 \mathrm{inch})$ and trinexapac-ethyl application $\left(0.15 \mathrm{~kg} \cdot \mathrm{ha}^{-1}\right.$ and nontreated control) treatments. Aesthetic performance was estimated by vegetation indices, spectral reflectance, visual TQ, and PGC. The functional performance of each variety/line was measured through surface firmness and fiber analysis. Regression analyses were similar when using only reference plots or all the plots to determine the relationship between individual aesthetic characteristics. Experimental line 04-47 had lower density in Apr. 2010, whereas varieties 'TifTuf', 'TifSport', and 'Tifway' were in the top statistical group for aesthetic performance when differences were found. 'TifSport' and 'Tifway' produced the firmest surfaces, followed by 'Tif'Tuf', and finally 04-76 and 04-47, which provided the least firm surface. Results of leaf fiber analysis were not correlated with turf surface firmness. This study indicates that incorporating quantitative measures of spectral reflectance could reduce time and improve precision of data collection as long as reference plots with adequate range of green cover are present in the trials.

$\mathrm{F}$ or decades, visual assessments of turfgrass color, density, uniformity, quality, and cover have been used in variety trials (Horst et al., 1984; Morris, 2000). The National Turfgrass Evaluation Program (NTEP) developed protocols for visually assessing turfgrasses, which are widely used

${ }^{1}$ Turf Scout LLC., P.O. Box 14768, Greensboro, NC 27415

${ }^{2}$ Department of Crop \& Soil Sciences, University of Georgia, 2360 Rainwater Road, Tifton, GA 31793

${ }^{3}$ Department of Horticulture, OR State University, 4147 ALS Building, Corvallis, OR 97331

${ }^{4}$ Department of Agricultural Leadership, Education, and Communication, University of Georgia, 2360 Rainwater Road, Tifton, GA 31793

${ }^{5}$ Crop Genetics and Breeding Research Unit, USDA/ ARS, P.O. Box 748, Tifton, GA 31793

${ }^{6}$ Department of Crop \& Soil Sciences, University of Georgia, 1109 Experiment Street, Griffin, GA 30223

${ }^{7}$ Corresponding author. E-mail: jingzhang687@ufl.edu. doi: 10.21273/HORTTECH03436-16 and recognized by turf researchers (Morris and Shearman, 1998). In recent years, more quantitative methods (i.e., digital image analysis and spectral reflectance) have been developed to supplement visual ratings to minimize subjectivity. For example, spectral reflectance from turfgrass canopies has been used for quantifying turfgrass cover and/or quality (Jiang and Carrow, 2007; Trenholm et al., 1999; Xiong et al., 2007). Spectral reflectance of a turfgrass canopy is a function of absorption of visible light by chlorophyll and carotene content (amount not type) (Daughtry, 2000; Jacquemoud et al., 1996), whereas reflectance of near-IR (NIR) light is associated with water and leaf turgor, which attenuate absorbance features associated with lignin and cellulose (Murphy, 1995). These characteristic features of plant reflectance make remote sensing technologies an ideal method for quantitatively assessing turf quality attributes. Despite many efforts to establish the relationship between spectral reflectance and turfgrass cover and/or quality (Bell et al., 2013), its direct and practical use in turfgrass science has not yet been proposed. If selected reference plots can be used to determine the relationship between spectral reflectance and turfgrass cover and/or quality with regression, there is potential to reduce the number of visual ratings or photographic images needed in a large variety trial.

Hybrid bermudagrasses have been widely used on golf courses, athletic fields, residential, and commercial landscapes due to their high aesthetic appearance, tolerance to variable mowing heights, and good recuperative ability from traffic (Beard, 2002; Karcher et al., 2005; Trenholm et al., 2000 b). In variety trials, evaluation of genotypic responses to different cultural practices provides valuable information on the management of experimental lines once they are released. Cultural practices such as frequent mowing at varying heights and trinexapac-ethyl (TE) application are routine maintenance for bermudagrass. The effects of TE on growth inhibition are well documented in many turfgrass species (Ervin et al., 2002; McCarty et al., 2004; McCullough et al., 2007). Other positive effects of TE include increased chlorophyll content levels (Ervin and Koski, 2001), turfgrass quality (Jiang and Fry, 1998), and

\begin{tabular}{lllc}
\hline $\begin{array}{l}\text { Units } \\
\begin{array}{l}\text { To convert U.S. to SI, } \\
\text { multiply by }\end{array}\end{array}$ & U.S. unit & SI unit & $\begin{array}{l}\text { To convert SI to U.S., } \\
\text { multiply by }\end{array}$ \\
\hline 0.3048 & $\mathrm{ft}$ & $\mathrm{m}$ & 3.2808 \\
0.0929 & $\mathrm{ft}^{2}$ & $\mathrm{~m}^{2}$ & 10.7639 \\
2.54 & inch $(\mathrm{es})$ & $\mathrm{cm}$ & 0.3937 \\
25.4 & inch $(\mathrm{es})$ & $\mathrm{mm}$ & 0.0394 \\
0.4536 & $\mathrm{lb}$ & $\mathrm{kg}$ & 2.2046 \\
1.1209 & $\mathrm{lb} / \mathrm{acre}$ & $\mathrm{kg} \cdot \mathrm{ha}^{-1}$ & 0.8922 \\
28.3495 & $\mathrm{oz}$ & $\mathrm{g}$ & 0.0353
\end{tabular}


turfgrass performance under abiotic stress (Ervin et al., 2002; McCann and Huang, 2007).

Besides aesthetic performance, functional performance such as surface firmness is also an important characteristic of hybrid bermudagrasses, because they are widely used on athletic fields and golf courses. Surface firmness has been directly associated with injuries and playability (Beard and Green, 1994). Surface firmness can be influenced by multiple factors such as turfgrass variety, thatch accumulation, soil moisture content, soil texture, bulk density, and management practices (Linde et al., 2011). Devices such as the Clegg impact soil tester [CIST (Lafayette Instrument Co., Lafayette, IN)] or TruFirm turf firmness meter (U.S. Golf Association, 2009) can be used to measure surface firmness. An inverse relationship $\left(R^{2}=0.75\right)$ was found between the two devices when they were used to measure putting green firmness with different soil physical conditions (Linde et al., 2011). Fiber analyses provide an estimate of leaf fiber content (i.e., lignin), which has been reported to be associated with turf wear tolerance (Shearman and Beard, 1975; Trenholm et al., 2000a), leaf texture, and thatch accumulation (Meinhold et al., 1973). The association of leaf fiber content and surface firmness has yet to be determined.

The objectives of the study were 1) to establish a relationship between spectral reflectance and TQ and PGC using selected reference plots; 2) to compare aesthetic performance (TQ, PGC, and vegetation indices) and functional performance (surface firmness) among three hybrid bermudagrass varieties and two experimental lines; and 3 ) to investigate if turfgrass lignin content as estimated by fiber analysis is useful to predict surface firmness of hybrid bermudagrasses in a variety trial under different mowing heights and TE application.

\section{Materials and methods}

Turfgrass research plots $(19 \times 19$ $\mathrm{ft})$ were established vegetatively from plugs in May 2008 on a loamy sand (Tifton-Urban land complex, $\mathrm{pH}$ 5.3) at the University of Georgia Tifton Campus. Plots were arranged as a completely randomized strip plot design, where whole plots corresponded to experimental lines (04-47 and 04-76) and varieties ('TifTuf', 'TifSport', and 'Tifway'), representing a range in leaf texture, genetic green color, and turf density within the hybrid bermudagrass species (Table 1). The subplot factors were mowing height ( 0.5 or 1.5 inch) and plant growth regulator (PGR) application [nontreated control (NTC) or TE at $0.15 \mathrm{~kg} \cdot \mathrm{ha}^{-1}$ (Primo MAXX; Syngenta, Greensboro, NC)]. The application of TE was monthly from Mar. to Oct. 2009, 2010, and 2011. Plots were mowed twice weekly and fertilized monthly with $16 \mathrm{~N}-1.8 \mathrm{P}-8.6 \mathrm{~K}$ (Super Rainbow Plant Food; Agrium U.S., Denver, CO) at rates ranging from 24 to $48 \mathrm{~kg} \cdot \mathrm{ha}^{-1}$ nitrogen $(\mathrm{N})$ from April to October, totaling 366 $\mathrm{kg} \cdot \mathrm{ha}^{-1} \mathrm{~N}$ annually. Plots also received daily irrigation $(0.15 \mathrm{inch} / \mathrm{d})$ during the growing season.

Ground truth and remotely sensed data were collected concurrently four times: 29 Apr. 2010, 18 June 2010, 27 Apr. 2011, and 28 June 2011. Spring assessments were selected as a benchmark for turfgrass leaving dormancy and summer assessments were selected as a benchmark for turfgrass at the peak growth. Ground truth consisted of visual ratings of TQ, PGC, and canopy reflectance. Visual TQ ratings were collected by a single researcher using a scale of 1 to 9 , where 1 equaled a dead plot, 6 and greater being acceptable, and 9 being optimum turf (Morris and Shearman, 1998). PGC was estimated from digital images collected using a digital camera (Powershot G5; Canon, Tokyo, Japan) mounted to an enclosed photo box $\left(0.31 \mathrm{~m}^{2}\right)$ with four $9-\mathrm{W}$ compact fluorescent lamps (TCP; Lighthouse Supply, Bristol, VA). Each image was analyzed using SigmaScan Pro (version 5.0; Systat Software, San Jose, CA) for PGC (0\% to $100 \%)$ using

Table 1. Leaf texture, color, and density of two hybrid bermudagrass experimental lines and three varieties evaluated at Tifton, GA, in 2010 and 2011.

\begin{tabular}{llll}
\hline Variety/line & $\begin{array}{c}\text { Leaf } \\
\text { texture }\end{array}$ & \multicolumn{1}{c}{ Color } & Density \\
\hline $04-47$ & Coarse & Dark green & Moderate \\
$04-76$ & Coarse & Dark green & Poor \\
'TifSport' & Fine & Light green & Dense \\
'TifTuf' & Fine & Moderate green & Dense \\
'Tifway' & Fine & Moderate green & Dense \\
\hline
\end{tabular}

a hue range from 60 to 120 and saturation range from 10 to 100 as outlined by Richardson et al. (2001). Canopy reflectance was measured using a canopy sensor (CropCircle ACS470; Holland Scientific, Lincoln, $\mathrm{NE}$ ), equipped with a decimeter level global positioning system [GPS (Raven Industries, Sioux Falls, SD)]. The canopy sensor measured light reflectance in three spectral bands centered on 550 (green), 650 (red), and $730 \mathrm{~nm}$ (NIR) using a modulated polychromatic light-emitting diode array (emission form 430-850 nm). The modulated, active light source adjusts for differences in ambient light conditions during data collection. The sensor has a field of view of $32^{\circ} \times 6^{\circ}$, and collects 10 samples per second. The system was mounted to a mobile cart at $\approx 2 \mathrm{ft}$ aboveground with a target area of $35 \times 6.4 \mathrm{~cm}$. Data were collected between 10:00 AM and 2:00 $\mathrm{PM}$, recorded to a data card and processed using the TurfScout ${ }^{\circledR}$ platform (TurfScout, Greensboro, NC). TurfScout ${ }^{\circledR}$ outputs cleaned, clipped, and labeled data to a standardized output and map file. Cleaning consists of eliminating data points that are above or below the established tolerances for expected reflectance. The outputs (plot and treatment summaries of reflectance) were used to relate spectral reflectance to PGC and TQ. In addition to the individual spectral bands, two common vegetative indices were evaluated: ratio vegetation index (RVI) and normalized difference vegetation index (NDVI) as follows:

$$
\begin{gathered}
\text { RVI }=\frac{\text { NIR }}{\text { Red }} \\
\text { NDVI }=\frac{(\text { NIR }- \text { Red })}{(\text { NIR }+ \text { Red })}
\end{gathered}
$$

Surface firmness was measured in Dec. 2009 and Jan. 2011 using a 2.25-kg CIST and the TruFirm turf 
firmness meter. For the CIST, the ratio of maximum negative acceleration on impact in units of gravities to the acceleration due to gravity $\left(\mathrm{G}_{\max }\right)$ from the first and fourth drop was recorded, and within $5 \mathrm{~cm}$ of the indent, the hammer of the turf firmness meter was dropped and the first reading was recorded.

Leaf samples were collected in Jan. 2011 and the tissues were individually ground in a Wiley mill (1 mm). Samples of dried material were also used for quality determinations, which included in vitro dry matter digestibility (IVDMD), neutral detergent fiber (NDF), and acid detergent fiber (ADF), which were estimated by near-IR spectroscopy (NIRS) (Foss NIRSystems, Silver Spring, MD) from calibrations previously determined. To verify NIRS estimates, triplicate ground samples $(0.5 \mathrm{~g})$ from representative treatment entries were subjected to IVDMD as described by Tilley and Terry (1963) and modified by Marten and Barnes (1980). Fiber analyses including NDF and ADF were determined sequentially (Van Soest et al., 1991) using the Ankom filter bag (Ankom Technology Corp., Fairport, NY) method (Vogel et al., 1999).

Data analysis. All data were subjected to an analysis of variance using SAS (version 9.4; SAS Institute,
Cary, NC). Due to a significant interaction between date and variety/ line, parameters including PGC, NDVI, and TQ were presented by date. Means were separated using Tukey's honestly significant difference test. There was no interaction found for surface firmness measurements, thus data from different dates were pooled and a covariance component was included in the model. Relationships between spectral outputs, TQ and PGC, were evaluated using basic regression and Pearson correlation in SigmaStat (version 3.5, Systat Software). Factors included sampling date, hybrid bermudagrass varieties/lines, mowing height, and TE applications. Pearson correlation coefficients were used to evaluate the strength of the relationship between TQ or PGC and reflectance variables (RVI, NDVI, red, green, and blue). For each sampling date, 11 standard reference plots were selected at uniform intervals of NDVI or RVI across the range of data. Regression relationships were then fitted between the reference plots and vegetation indices (NDVI and RVI). In practice, reference plots could be used to minimize the number of light box images or turf quality ratings necessary to adequately predict PGC and TQ at unsampled locations using reflectance measurements as a proxy. Observed root mean square error (RMSE) was calculated based on the estimates of PGC or TQ from both 11 reference plots and all the data points using fitted models.

\section{Results and discussion}

EVALUATING HYBRID BERMUDAGRASS USING SPECTRAL REFLECTANCE. Positive relationships were found between PGC and vegetation indices (RVI and NDVI) as indicated by Pearson correlation coefficients at four sampling dates, ranging from 0.61 to $0.87(\alpha=0.05$, Table 2$)$. This agreed with previous studies reporting that NDVI is correlated closely with density and percent live cover of the turf canopy (Bell et al., 2002; Bremer et al., 2011; Trenholm et al., 1999). Percent green cover was negatively correlated with spectral reflectance in the red and green bands, and it was positively correlated with NIR reflectance, similar to what was observed by Bremer et al. (2011), who also found that the greater absorption of red light resulted from higher leaf chlorophyll content. In our study, the higher chlorophyll content was mostly attributed to higher PGC. Nonvisible NIR reflectance is primarily associated with internal leaf scattering (Knipling, 1970) and its increase was probably due to the lower number of senesced leaves at higher PGC. Data collected

Table 2. Pearson correlation coefficients between percent green cover (PGC) and vegetation indices normalized difference vegetation index (NDVI) and ratio vegetation index (RVI), and spectral reflectance at red, near-IR (NIR), and green bands of three hybrid bermudagrass varieties and two experimental lines evaluated at Tifton, GA, in 2010 and 2011.

\begin{tabular}{|c|c|c|c|c|c|c|c|c|c|c|c|}
\hline \multirow[b]{2}{*}{ Data set } & \multirow[b]{2}{*}{ Sample size } & \multirow[b]{2}{*}{ RVI } & \multirow[b]{2}{*}{ NDVI } & \multirow[b]{2}{*}{ Red } & \multirow[b]{2}{*}{ NIR } & \multirow[b]{2}{*}{ Green } & \multicolumn{5}{|c|}{ PGC } \\
\hline & & & & & & & Minimum & Maximum & Mean & SD & $\mathrm{CV}$ \\
\hline All data & 240 & 0.65 & 0.76 & -0.75 & 0.38 & -0.21 & 16.3 & 99.0 & 83.0 & 14.2 & 17.1 \\
\hline All Apr. 2011 & 60 & 0.71 & 0.85 & -0.79 & 0.65 & -0.36 & 16.3 & 98.1 & 87.5 & 12.4 & 14.1 \\
\hline All June 2010 & 60 & 0.61 & 0.62 & -0.55 & 0.39 & -0.23 & 69.8 & 95.3 & 85.1 & 7.0 & 8.3 \\
\hline All June 2011 & 60 & 0.67 & 0.70 & -0.59 & 0.49 & -0.22 & 55.9 & 96.4 & 85.9 & 8.1 & 9.5 \\
\hline
\end{tabular}

Table 3. Pearson correlation coefficients between turfgrass quality (TQ) and vegetation indices normalized difference vegetation index (NDVI) and ratio vegetation index (RVI), and spectral reflectance at red, near-IR (NIR), and green bands of three hybrid bermudagrass varieties and two experimental lines evaluated at Tifton, GA, in 2010 and 2011.

\begin{tabular}{|c|c|c|c|c|c|c|c|c|c|c|c|}
\hline \multirow[b]{2}{*}{ Data set } & \multirow[b]{2}{*}{ Sample size } & \multirow[b]{2}{*}{ RVI } & \multirow[b]{2}{*}{ NDVI } & \multirow[b]{2}{*}{ Red } & \multirow[b]{2}{*}{ NIR } & \multirow[b]{2}{*}{ Green } & \multicolumn{5}{|c|}{ TQ } \\
\hline & & & & & & & Minimum & Maximum & Mean & SD & $\mathrm{CV}$ \\
\hline All data & 240 & 0.34 & 0.43 & -0.48 & 0.12 & -0.18 & 2 & 9 & 6.1 & 1.6 & 26.1 \\
\hline All Apr. 2010 & 60 & 0.62 & 0.68 & -0.57 & 0.67 & -0.58 & 2 & 8 & 5.2 & 1.7 & 32.5 \\
\hline All Apr. 2011 & 60 & 0.50 & 0.55 & -0.56 & 0.31 & 0.34 & 3 & 8 & 6.4 & 1.2 & 19.4 \\
\hline All June 2010 & 60 & $\mathrm{NS}^{\mathrm{z}}$ & NS & NS & -0.33 & NS & 4 & 9 & 6.4 & 1.2 & 19.2 \\
\hline All June 2011 & 60 & NS & NS & -0.28 & 0.49 & NS & 3 & 9 & 6.3 & 1.8 & 28.5 \\
\hline
\end{tabular}

${ }^{\mathrm{z}} \mathrm{NS}=$ not significant at $P=0.05$. 
in April generally had higher correlation coefficients than in June, and this was due to a greater range in PGC in April compared with June (Table 2). Turfgrass quality in April was correlated with vegetation indices and spectral reflectance (Table 3 ); however, it was not correlated with vegetation indices in June and its relationship with spectral reflectance was also inconsistent compared with PGC. Lack of variability within the June dataset might be the reason why no correlation was established between TQ and the vegetation indices.

In general, the RVI and NDVI vegetative indices were both well correlated with PGC, but NDVI had slightly higher correlation coefficient than RVI. This could occur because NDVI is more sensitive when vegetation cover is sparse rather than fully covered, and the calculation of NDVI is designed to minimize spectral contributions from bare soil and senesced vegetation (Fitz-Rodríguez and Choi, 2002; Jensen, 2007). There have been fewer studies to determine the relationship between RVI and TQ and/or PGC. Most of the research has focused on using NDVI to predict TQ and/or PGC (Bremer et al., 2011; Trenholm et al., 1999; Xiong et al., 2007). In our trials, a quadratic relationship between RVI and PGC/ TQ was the best fit for both the reference plots $(\mathrm{n}=11$, (Figs. $1 \mathrm{~A}$ and $2 A)$ and all plots $(n=60$, Figs. $\mathrm{IB}$ and $2 \mathrm{~B}$ ), but a linear relationship was stronger between NDVI and PGC/TQ (Figs. IC, D and 2C, D). Figures 1 and 2 only demonstrate the regression results from Apr. 2010. Regression analysis from other sampling dates is listed in Table 4. Regression results from the 11 reference plots well represented regression results using all data points as indicated by similar RMSEs from each, except in the summer 2010, where a significant relationship between RVI and PGC was not found in the reference plots. Moreover, due to the narrow range of data collected in summer (June), the ability to predict PGC or TQ based on RVI or NDVI was limited in our study. Therefore, when reference plots for future variety trials are selected, standard varieties that exhibit a wide range in PGC should be included. Nevertheless, our results indicated that spectral reflectance has promise as a tool to
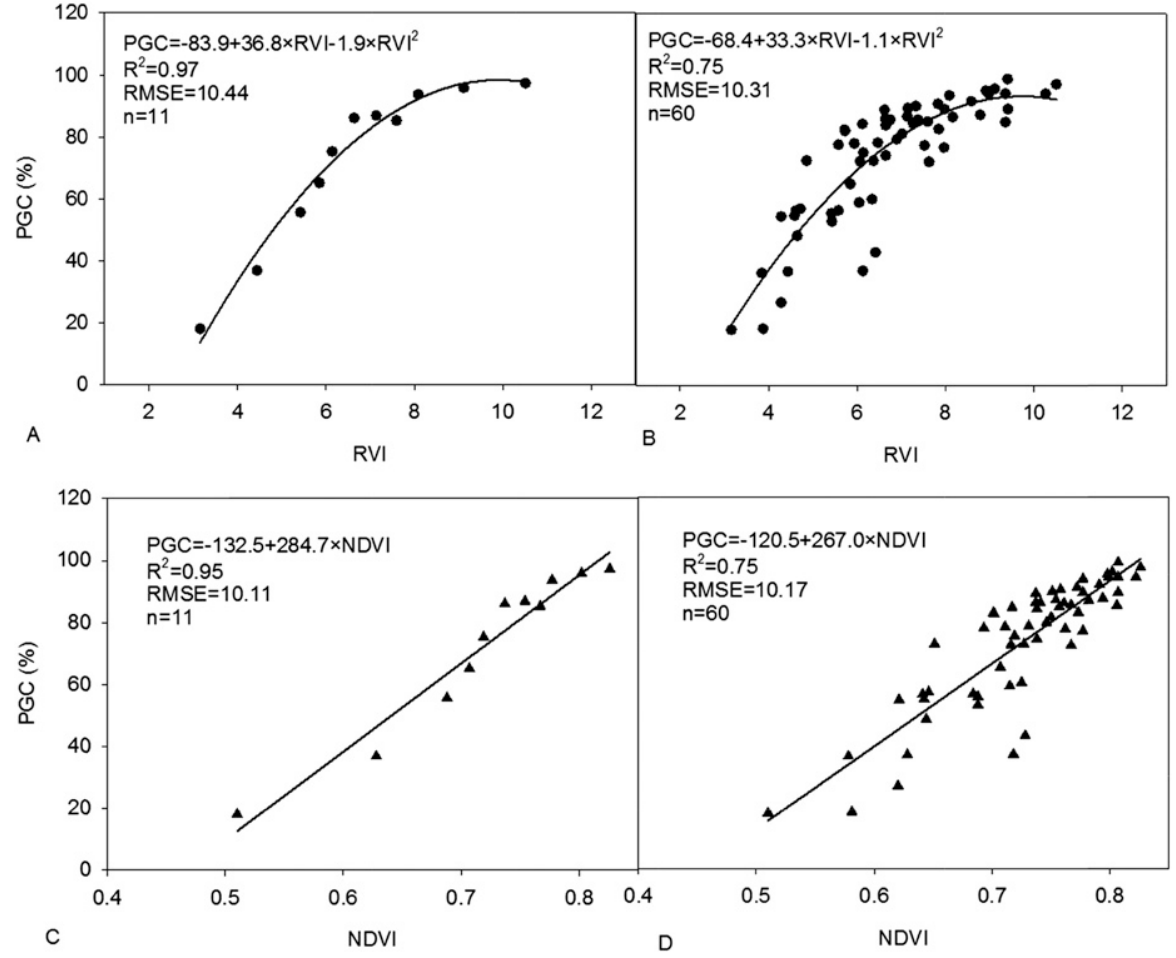

Fig. 1. Regression results of ratio vegetation index (RVI) vs. percent green cover (PGC) and normalized difference vegetation index (NDVI) vs. PGC of three hybrid bermudagrass varieties and two experimental lines evaluated in Spring 2010 at Tifton, GA. (A) Eleven data points were used to fit the regression between RVI and PGC; (B) all the data points were used; (C) 11 data points were used to fit the regression between NDVI and PGC; (D) all the data points were used. Observed root mean square error (RMSE) of all the models were calculated based on all data points collected.

incorporate quantitative measures of turfgrass performance during the selection process, and at the same time, reduce the time and labor involved for data collection. If the goal was to differentiate treatment effects, a regression may not be necessary, as an analysis of variance on spectral reflectance data would be sufficient. Regression between spectral reflectance and PGC or TQ would translate the data into more comparable results.

Aesthetic tURF PERFORMANCe AS AFFECTED BY VARIETY/LINE, MOWING HEIGHT AND TE APPLICATION. Aesthetic turf performance of the evaluated hybrid bermudagrass indicated by TQ, PGC, and vegetation indices were affected differently by the management treatments of mowing height and TE application in all four sampling dates (Tables 5-7). In Apr. 2010, the PGC of hybrid bermudagrass was affected by variety/line, mowing height, and $\mathrm{TE}$ application (Table 5). The three-way interaction was caused by the lack of response of 'Tifway' mowed at 0.5 inch to the TE application (data not shown). 'TifTuf' (88.6\%) had greater PGC than 04-47 (49\%) and 04-76 $(68.7 \%)$. Both higher mowing height and TE application increased PGC. Mowing height was the only significant factor in June 2010, although the differences were minimal $(3.7 \%$ in PGC difference). No significant treatment effects were found in Apr. 2011, and variation of PGC among varieties/lines in June 2011 was minimal $(84.3 \%$ to $92 \%)$. On average, the hybrid bermudagrasses under TE application had $2.5 \%$ more PGC than the NTC plots. The effect of variety/ line, mowing height, and TE application on the NDVI was similar to PGC in Apr. 2010 (Table 6), and the effect of mowing height extended into June 2010 and Apr. 2011. Both the experimental lines 04-47 and 04-76 have coarse leaf texture and dark green color. The reduced density of 04-47 in Apr. 2010 was partly due to slower spring green-up; however, throughout the remainder of the study, the NDVI and PGC of 04-47 increased 

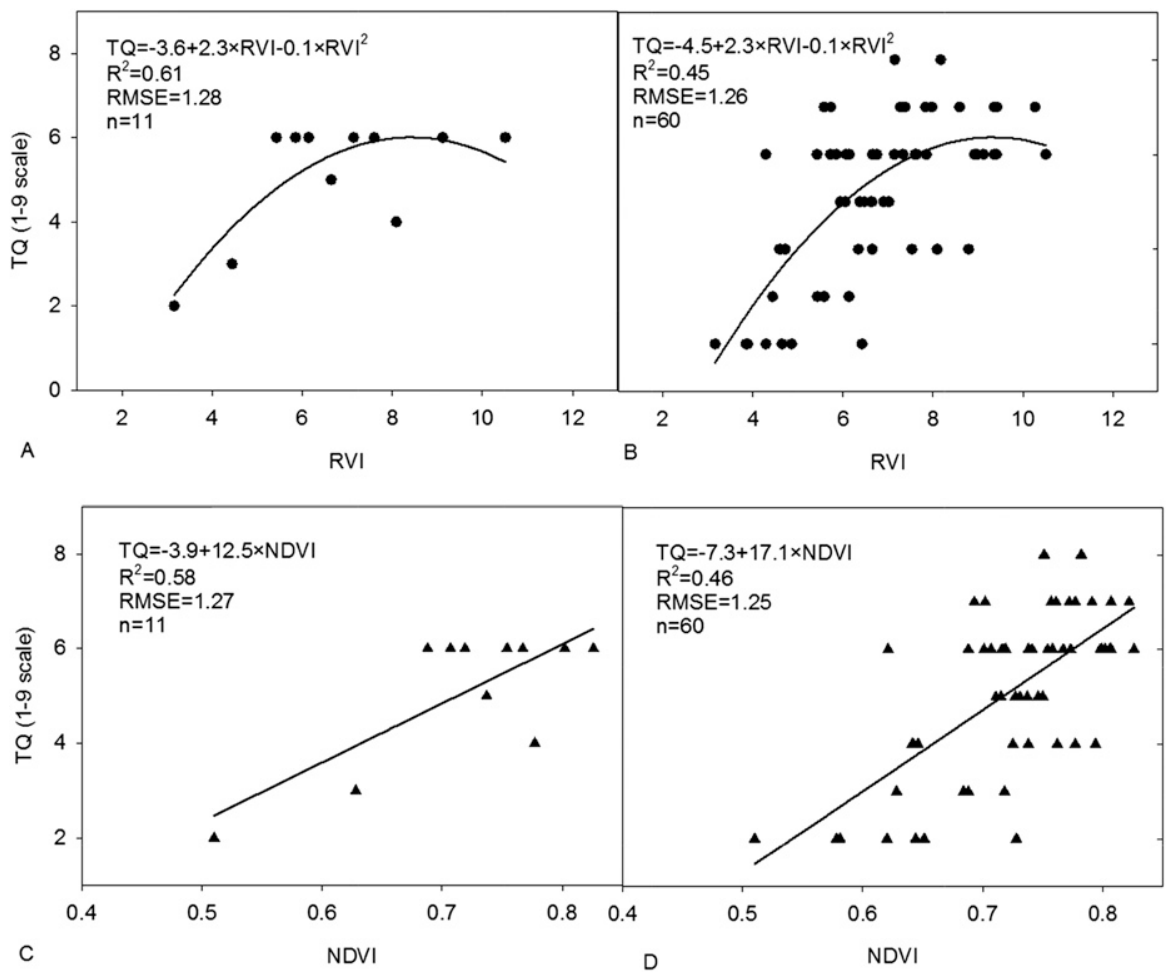

Fig. 2. Regression results of ratio vegetation index (RVI) vs. turfgrass quality (TQ) and normalized difference vegetation index (NDVI) vs. TQ of three hybrid bermudagrass varieties and two experimental lines evaluated in Spring 2010 at Tifton, GA. (A) Eleven data points were used to fit the regression between RVI and TQ; (B) all the data points were used; (C) 11 data points were used to fit the regression between NDVI and TQ; (D) all the data points were used. Observed root mean square error (RMSE) of all the models were calculated based on all data points collected.

and remained in the top statistical grouping. 'TifTuf' forms a dense canopy with fine leaf texture and is lighter green. Its overall aesthetic performance was in the top statistical group, except for lower NDVI than 04-47 in June 2010. 'TifSport' and 'Tifway' have been standards within the industry for decades and possess a relatively fine leaf texture, moderate green color, and strong density. Their aesthetic performances were similar to 'TifTuf' in this well-irrigated variety trial.

Measurements of PGC and NDVI agreed with each other and were equally adequate in differentiating treatments in our study. Visual ratings of TQ were less sensitive in finding differences among treatments. In Apr. 2010, the TQ of hybrid bermudagrass varieties/lines was not impacted by TE application, except for in 04-76 where TQ increased with TE application (Table 7). 'TifTuf' treated with TE had better TQ than 04-47 and 04-76 in the NTC. In June 2010, differences among varieties/lines and
TE application were not found, but the average TQ at 0.5 -inch mowing height was greater than when mowed at 1.5 inch. In Apr. 2011, the TQ of plots at the lower mowing height increased under TE application, but in June 2011, the average TQ of hybrid bermudagrasses in the 1.5 -inch mowing height treatment decreased under $\mathrm{TE}$ application. In general, there were no consistent effects throughout the year associated with TE or mowing height treatments. Lower mowing height tended to have higher TQ in summer (June), and the effect of TE application was inconclusive. Increased turfgrass density and TQ have been reported in bermudagrass treated with TE (McCarty et al., 2011), but Kowalewski et al. (2014) reported a decline in TQ on hybrid bermudagrass under TE application coupled with reduced frequency of mowing.

FUNCTIONAL TURF PERFORMANCE AS INDICATED BY SURFACE FIRMNESS AND FIBER ANALYSIS. Surface firmness varied among hybrid bermudagrasses for both the first and the fourth $G_{\max }$ readings from the CIST (Fig. 3A and B). In these trials, 'TifSport' and 'Tifway' had the firmest surfaces, 04-76 and 04-47 had the least firm surfaces, and 'TifTuf' was in between (Fig. 3B). The TruFirm turf firmness meter provided less separation among accessions, but both methods found 04-47 to have the least firm surface (Fig. 3C). Turf firmness meter measurements also indicated that the lower mowing height resulted in firmer playing surfaces than grasses mowed at the higher height (Fig. 3D). Pearson correlation coefficients found that turf firmness meter measurements were inversely correlated with those from the CIST $(-0.34, P<$ 0.01 , Table 8). Linde et al. (2011) also reported that both of the devices were useful in measuring surface firmness. In our research, the reading of the fourth drop seemed to provide more genotypic separation and was better correlated with the turf firmness meter compared with the first drop reading. Additionally, there were no correlations found between surface firmness and the individual estimates from the fiber analysis, which was partly due to lack of variation in $\mathrm{NDF}$ and ADF among the varieties/ lines included in this study. Further research among wider selection of bermudagrass varieties is needed to determine if a genotypic relationship for surface firmness is present.

In summary, this study demonstrated that spectral reflectance is a promising tool for incorporating quantitative measures of turfgrass performance into a variety trial, while potentially reducing the time and labor involved in data collection efforts if reference plots with adequate range of green cover can be included. Both RVI and NDVI were good indicators of PGC and TQ when variability was present. This study was conducted across multiple factors such as variety/line, mowing height, and TE application. No significant interaction of vegetation indices was found between any combinations of factors except for sampling date (Table 6), which suggests that it is not necessary to separate treatments when predicting PGC and/or TQ based on vegetation indices, but ground truth measurement of PGC and/or TQ need to be collected simultaneously with spectral reflectance on standard reference varieties. The aesthetic performance of 
Table 4. Regression results of normalized difference vegetation index (NDVI) vs. percent green cover (PGC), ratio vegetation index (RVI) vs. PGC, NDVI vs. turfgrass quality (TQ), and RVI vs. TQ of three hybrid bermudagrass varieties and two experimental lines evaluated in Apr. and June 2010 and 2011 at Tifton, GA.

\begin{tabular}{|c|c|c|c|c|c|c|}
\hline \multirow[b]{2}{*}{ Regression } & \multicolumn{3}{|l|}{$\mathrm{n}=11^{\mathrm{z}}$} & \multicolumn{3}{|l|}{$\mathrm{n}=60^{\mathrm{y}}$} \\
\hline & Model & $R^{2}$ & RMSE $^{\mathrm{x}}$ & Model & $R^{2}$ & RMSE \\
\hline \multicolumn{7}{|c|}{ NDVI vs. PGC } \\
\hline June 2010 & $\mathrm{PGC}=-54.3+178.4 \times \mathrm{NDVI}$ & $0.47^{*}$ & 5.71 & $\mathrm{PGC}=-35.5+156.0 \times \mathrm{NDVI}$ & $0.38 * * *$ & 5.55 \\
\hline Apr. 2011 & $\mathrm{PGC}=-78.0+223.3 \times \mathrm{NDVI}$ & $0.85 * * *$ & 6.61 & $\mathrm{PGC}=-58.6+197.0 \times \mathrm{NDVI}$ & $0.72 * * *$ & 6.57 \\
\hline June 2011 & $\mathrm{PGC}=-20.0+144.5 \times \mathrm{NDVI}$ & $0.78 * * *$ & 5.82 & $\mathrm{PGC}=-26.8+155.0 \times \mathrm{NDVI}$ & $0.48 * * *$ & 5.84 \\
\hline June 2010 & $\mathrm{n} / \mathrm{a}^{\mathrm{w}}$ & NS & $\mathrm{n} / \mathrm{a}$ & $\begin{array}{l}\mathrm{PGC}=26.9+10.7 \times \mathrm{RVI}-0.42 \\
\quad \times \mathrm{RVI}^{2}\end{array}$ & $0.36^{* * *}$ & 5.61 \\
\hline Apr. 2011 & $\begin{array}{l}\mathrm{PGC}=-82.3+45.9 \times \mathrm{RVI}-3.0 \\
\quad \times \mathrm{RVI}^{2}\end{array}$ & $0.89 * * *$ & 6.31 & $\begin{array}{l}\mathrm{PGC}=-62.8+39.1 \times \mathrm{RVI}-2.5 \\
\quad \times \mathrm{RVI}^{2}\end{array}$ & $0.75 * * *$ & 6.22 \\
\hline June 2010 & $\mathrm{n} / \mathrm{a}$ & NS & $\mathrm{n} / \mathrm{a}$ & $\mathrm{n} / \mathrm{a}$ & NS & $\mathrm{n} / \mathrm{a}$ \\
\hline Apr. 2011 & $\mathrm{TQ}=-1.9+11.1 \times \mathrm{NDVI}$ & $0.70 * * *$ & 1.02 & $\mathrm{TQ}=-3.1+12.8 \times \mathrm{NDVI}$ & $0.29 * * *$ & 1.04 \\
\hline June 2011 & $\mathrm{n} / \mathrm{a}$ & NS & $\mathrm{n} / \mathrm{a}$ & $\mathrm{n} / \mathrm{a}$ & NS & $\mathrm{n} / \mathrm{a}$ \\
\hline \multicolumn{7}{|l|}{ RVI vs. TQ } \\
\hline Apr. 2010 & $\begin{array}{l}\mathrm{TQ}=-3.6+2.3 \times \mathrm{RVI}-0.1 \\
\times \mathrm{RVI}^{2}\end{array}$ & $0.51^{*}$ & 1.28 & $\begin{array}{l}\mathrm{TQ}=-4.5+2.3 \times \mathrm{RVI}-0.1 \\
\times \mathrm{RVI}^{2}\end{array}$ & $0.43^{* * *}$ & 1.26 \\
\hline June 2010 & $\mathrm{n} / \mathrm{a}$ & NS & NS & $\mathrm{n} / \mathrm{a}$ & NS & $\mathrm{n} / \mathrm{a}$ \\
\hline Apr. 2011 & $\begin{array}{l}\mathrm{TQ}=-0.8+1.7 \times \mathrm{RVI}-0.1 \\
\times \mathrm{RVI}^{2}\end{array}$ & $0.66^{* *}$ & 1.02 & $\mathrm{TQ}=-2.1+2.1 \times \mathrm{RVI}-0.1 \times \mathrm{RVI}^{2}$ & $0.29 * * *$ & 1.04 \\
\hline June 2011 & $\mathrm{n} / \mathrm{a}$ & NS & $\mathrm{n} / \mathrm{a}$ & $\mathrm{n} / \mathrm{a}$ & NS & $\mathrm{n} / \mathrm{a}$ \\
\hline $\begin{array}{l}\text { RMSE = root } \mathrm{m} \\
{ }^{\mathrm{z}} \text { Regression fitte } \\
{ }^{y} \text { Regression fitte } \\
{ }^{\mathrm{x}} \text { Observed RMS } \\
{ }^{\mathrm{w}} \text { Not applicable } \\
{ }_{*}{ }_{* * * *}\end{array}$ & $\begin{array}{l}\text { error. } \\
\text { n } 11 \text { reference plots. } \\
\text { n all plots. } \\
\text { odel was calculated based on all data } \\
\text { e model was not significant. }\end{array}$ & 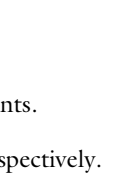 & & & & \\
\hline
\end{tabular}

Table 5. Percent green cover (PGC) of three hybrid bermudagrass varieties and two experimental lines (Variety) as affected by different mowing height (MH), and plant growth regulator (PGR) application in Apr. and June 2010 and 2011 at Tifton, GA.

\begin{tabular}{|c|c|c|c|c|c|}
\hline \multirow{2}{*}{\multicolumn{2}{|c|}{ Treatment }} & Apr. 2010 & June 2010 & Apr. 2011 & June 2011 \\
\hline & & \multicolumn{4}{|c|}{ PGC (\%) } \\
\hline \multirow[t]{4}{*}{ Variety/line } & $04-47$ & $49.0 c^{z}$ & $-^{y}$ & - & $92.0 \mathrm{a}$ \\
\hline & 'TifTuf' & $88.6 \mathrm{a}$ & - & - & $89.5 \mathrm{ab}$ \\
\hline & 'TifSport' & $84.6 \mathrm{ab}$ & - & - & $84.3 \mathrm{ab}$ \\
\hline & ‘Tifway’ & $76.7 \mathrm{ab}$ & - & - & $85.1 \mathrm{ab}$ \\
\hline \multirow[t]{2}{*}{$\mathrm{PGR}^{\mathrm{w}}$} & NTC & $67.6 \mathrm{~b}$ & - & - & $84.6 \mathrm{~b}$ \\
\hline & $\mathrm{TE}$ & $79.5 \mathrm{a}$ & - & - & $87.1 \mathrm{a}$ \\
\hline \multirow[t]{3}{*}{$P$ value } & Variety & 0.0003 & $\mathrm{NS}^{\mathrm{y}}$ & NS & 0.029 \\
\hline & $\mathrm{MH}$ & 0.0026 & 0.0195 & NS & NS \\
\hline & Variety $\times \mathrm{MH}$ & NS & NS & NS & NS \\
\hline
\end{tabular}

${ }^{\mathrm{z}}$ Means followed by the same letter within each treatment are not significant different.

yTreatment effect is not significant (NS) or it is included in an interactive effect at $P=0.05$.

${ }^{\mathrm{x}} \mathrm{l}$ inch $=2.54 \mathrm{~cm}$.

${ }^{\mathrm{W}} \mathrm{NTC}=$ nontreated control; TE $=$ trinexapac-ethyl application. 
Table 6. Normalized difference vegetation index (NDVI) of three hybrid bermudagrass varieties and two experimental lines (Variety) as affected by different mowing height (MH) and PGR application in Apr. and June 2010 and 2011 at Tifton, GA.

\begin{tabular}{|c|c|c|c|c|c|}
\hline \multirow{2}{*}{\multicolumn{2}{|c|}{ Treatment }} & Apr. 2010 & June 2010 & Apr. 2011 & June 2011 \\
\hline & & \multicolumn{4}{|c|}{ NDVI } \\
\hline \multirow[t]{5}{*}{ Variety/line } & $04-47$ & $0.67 \mathrm{~b}^{\mathrm{z}}$ & $0.81 \mathrm{a}$ & $-\mathrm{y}$ & $0.77 \mathrm{a}$ \\
\hline & 04-76 & $0.71 \mathrm{ab}$ & $0.78 \mathrm{ab}$ & - & $0.71 \mathrm{~b}$ \\
\hline & 'TifTuf' & $0.76 \mathrm{a}$ & $0.76 \mathrm{~b}$ & - & $0.73 \mathrm{ab}$ \\
\hline & 'TifSport' & $0.76 \mathrm{a}$ & $0.75 \mathrm{~b}$ & - & $0.70 \mathrm{~b}$ \\
\hline & 'Tifway' & $0.73 \mathrm{ab}$ & $0.76 \mathrm{~b}$ & - & $0.72 \mathrm{ab}$ \\
\hline \multirow[t]{2}{*}{$\mathrm{MH}^{\mathrm{x}}$} & 0.5 inch & $0.70 \mathrm{~b}$ & $0.76 \mathrm{~b}$ & $0.73 \mathrm{~b}$ & - \\
\hline & 1.5 inch & $0.76 \mathrm{a}$ & $0.78 \mathrm{a}$ & $0.75 \mathrm{a}$ & - \\
\hline \multirow{2}{*}{$\mathrm{PGR}^{\mathrm{w}}$} & NTC & $0.70 \mathrm{~b}$ & - & - & - \\
\hline & $\mathrm{TE}$ & $0.75 \mathrm{a}$ & - & - & - \\
\hline \multirow[t]{7}{*}{$P$ value } & Variety & 0.019 & 0.0016 & $\mathrm{NS}^{\mathrm{y}}$ & 0.0067 \\
\hline & $\mathrm{MH}$ & 0.0007 & 0.0064 & 0.0123 & NS \\
\hline & Variety $\times \mathrm{MH}$ & NS & NS & NS & NS \\
\hline & PGR & 0.0001 & NS & NS & NS \\
\hline & Variety $\times$ PGR & NS & NS & NS & NS \\
\hline & $\mathrm{MH} \times \mathrm{PGR}$ & NS & NS & NS & NS \\
\hline & Variety $\times \mathrm{MH} \times$ PGR & NS & NS & NS & NS \\
\hline
\end{tabular}

${ }^{\mathrm{z}}$ Means followed by the same letter within each treatment are not significant different.

${ }^{y^{2}}$ Treatment effect is not significant or it is included in an interactive effect at $P=0.05$; NS = not significant.

${ }^{\mathrm{x}} \mathrm{l}$ inch $=2.54 \mathrm{~cm}$.

${ }^{\mathrm{w}} \mathrm{NTC}=$ nontreated control; $\mathrm{TE}=$ trinexapac-ethyl application.

Table 7. Turfgrass quality (TQ) of three hybrid bermudagrass varieties and two experimental lines (Variety) as affected by different mowing height (MH) and plant growth regulator (PGR) application in Apr. and June 2010 and 2011 at Tifton, GA.

\begin{tabular}{|c|c|c|c|c|c|c|}
\hline \multirow{2}{*}{\multicolumn{3}{|c|}{ Treatment }} & Apr. 2010 & June 2010 & Apr. 2011 & June 2011 \\
\hline & & & \multicolumn{4}{|c|}{ TQ (1-9 scale) } \\
\hline $\mathrm{MH}^{\mathrm{z}}$ & \multicolumn{2}{|c|}{0.5 inch } & $-^{y}$ & $6.8 \mathrm{a}^{\mathrm{x}}$ & - & - \\
\hline PGR & \multicolumn{2}{|c|}{ NTC } & - & - & - & - \\
\hline & \multicolumn{2}{|c|}{$\mathrm{TE}$} & - & - & - & - \\
\hline \multirow{6}{*}{ Variety/line $\times$ PGR } & $04-47$ & $\mathrm{NTC}^{\mathrm{w}}$ & $3.0 \mathrm{c}$ & - & - & - \\
\hline & 'TifSport' & NTC & $5.2 \mathrm{a}-\mathrm{c}$ & - & - & - \\
\hline & ‘Tifway’ & NTC & $5.3 \mathrm{a}-\mathrm{c}$ & - & - & - \\
\hline & $04-47$ & $\mathrm{TE}^{\mathrm{v}}$ & $5.0 \mathrm{a}-\mathrm{c}$ & - & - & - \\
\hline & $04-76$ & $\mathrm{TE}$ & $6.2 \mathrm{a}$ & - & - & - \\
\hline & 'TifTuf' & $\mathrm{TE}$ & $6.5 \mathrm{a}$ & - & - & - \\
\hline \multirow{2}{*}{$\mathrm{MH} \times \mathrm{PGR}$} & 0.5 inch & $\mathrm{TE}$ & - & - & $6.7 \mathrm{a}$ & $7.4 \mathrm{a}$ \\
\hline & 1.5 inch & $\mathrm{TE}$ & - & - & $6.7 \mathrm{a}$ & $4.6 \mathrm{~b}$ \\
\hline \multirow[t]{7}{*}{$P$ value } & \multicolumn{2}{|c|}{ Variety } & $N S^{x}$ & NS & NS & NS \\
\hline & \multicolumn{2}{|c|}{$\mathrm{MH}$} & NS & 0.0074 & NS & 0.0007 \\
\hline & \multicolumn{2}{|c|}{ Variety $\times \mathrm{MH}$} & NS & NS & NS & NS \\
\hline & \multicolumn{2}{|c|}{ PGR } & $<0.0001$ & NS & 0.0286 & NS \\
\hline & \multicolumn{2}{|c|}{ Variety $\times$ PGR } & 0.0141 & NS & NS & NS \\
\hline & \multicolumn{2}{|c|}{$\mathrm{MH} \times \mathrm{PGR}$} & NS & NS & 0.0211 & 0.0004 \\
\hline & \multicolumn{2}{|c|}{ Variety $\times \mathrm{MH} \times$ PGR } & NS & NS & NS & NS \\
\hline 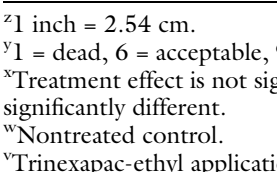 & $\begin{array}{l}\text { um turf. } \\
\text { it is include }\end{array}$ & active ef & $5 ;$ ss = not si & Means followe & letter with & ment are not \\
\hline
\end{tabular}



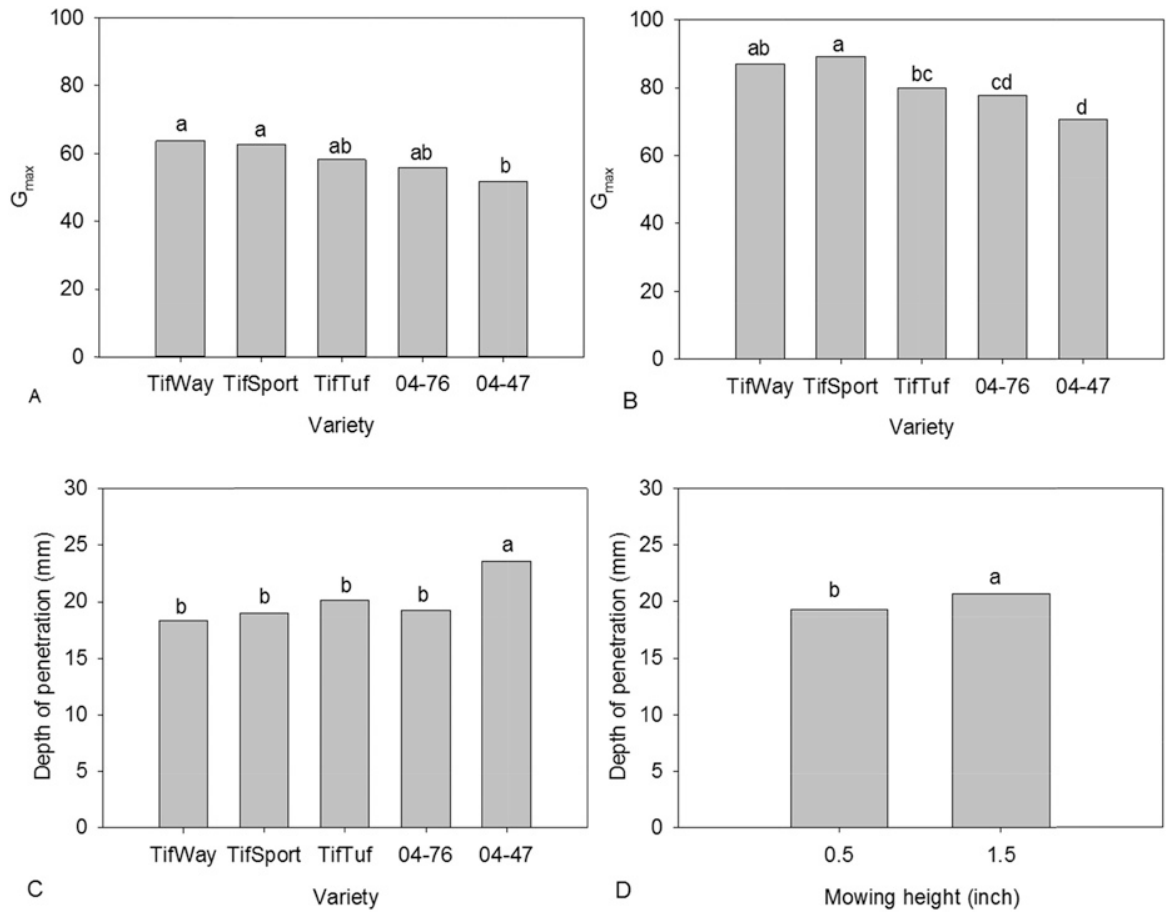

Fig. 3. Surface firmness of three hybrid bermudagrass varieties and two experimental lines (Variety) measured by the $2.25 \mathrm{~kg}(4.960 \mathrm{lb})$ Clegg impact soil tester (Lafayette Instrument Co., Lafayette, IN) at (A) the first drop and (B) fourth drop and (C and D) the turf firmness meter (TruFirm; U.S. Golf Association, Far Hills, NJ) in Dec. 2009 and Jan. 2011 at Tifton, GA. G max $_{\text {, an }}$ indicator of surface firmness, is the ratio of maximum negative acceleration on impact in units of gravities to the acceleration due to gravity. Columns with the same letter within a subfigure are not significantly different at $0.05 \mathrm{Plevel} ; \mathrm{l}$ inch = $2.54 \mathrm{~cm}, 1 \mathrm{~mm}=0.0394$ inch.

Table 8. Pearson correlation coefficients among surface firmness, $\mathbf{G}_{\max }$, measured by $2.25-\mathrm{kg}(4.960 \mathrm{lb})$ Clegg impact soil tester (Lafayette Instrument Co., Lafayette, IN) at the first and fourth readings, turf firmness meter (TruFirm; U.S. Golf Association, Far Hills, NJ) value, in vitro dry matter digestibility (IVDMD), neutral detergent fiber (NDF), and acid detergent fiber (ADF) in three hybrid bermudagrass varieties and two experimental lines evaluated at Tifton, GA, in 2011.

\begin{tabular}{lccccc}
\hline & G $_{\text {max }}$ fourth & TruFirm & NDF & IVDMD & ADF \\
\hline $\mathrm{G}_{\max }$ first & $0.82^{* * *}$ & $-0.26^{*}$ & $\mathrm{NS}$ & $\mathrm{NS}$ & NS \\
$\mathrm{G}_{\max }$ fourth & & $-0.34^{* *}$ & $\mathrm{NS}$ & $\mathrm{NS}$ & $\mathrm{NS}$ \\
TruFirm & & & $\mathrm{NS}$ & $\mathrm{NS}$ & $\mathrm{NS}$ \\
NDF & & & $-0.56^{* * *}$ & NS \\
IVDMD & & & & & NS \\
\hline
\end{tabular}

* ${ }^{* *},{ }^{* * *}$ Indicate significance level at $P=0.05,0.01,0.001$, respectively; NS $=$ not significant at $P=0.05$.

'TifTuf' was similar to 'TifSport' and 'Tifway', and was in the top statistical groups for all of these traits. 'TifSport' and 'Tifway' had firmer surfaces than 04-76 and 04-47, with 'TifTuf' falling in between when measured with both the CIST and turf firmness meter. Mowing the turf plots at a height of 1.5 inch also resulted in less firm surfaces than when mowed at a height of 0.5 inch. In addition, results of leaf fiber analysis were not correlated with turf surface firmness and more research is needed to determine if this tool can be used successfully in turfgrass breeding.

\section{Literature cited}

Beard, J. 2002. Turf management for golf courses. Ann Arber Press, Chelsea, MI.

Beard, J. and R. Green. 1994. The role of turfgrasses in environmental protection and their benefits to humans. J. Environ. Qual. 23(3):452-460.
Bell, G., J. Kruse, and J. Krum. 2013. The evolution of spectral sensing and advances in precision turfgrass management, $\mathrm{p}$. 1151-1188. In: J. Stier, B. Horgan, and S. Bonos (eds.). Turfgrass: Biology, use and management. Agron. Monogr. 56. Amer. Soc. Agron., Soil Sci. Soc. Amer., Crop Sci. Soc. Amer., Madison, WI.

Bell, G.E., D.L. Martin, S.G. Wiese, D.D. Dobson, M.W. Smith, M.L. Stone, and J.B. Solie. 2002. Vehicle-mounted optical sensing. Crop Sci. 42(1):197-201.

Bremer, D.J., H. Lee, K. Su, and S.J. Keeley. 2011. Relationships between normalized difference vegetation index and visual quality in cool-season turfgrass: II. Factors affecting NDVI and its component reflectances. Crop Sci. 51(5):2219-2227.

Daughtry, C. 2000. Estimating corn leaf chlorophyll concentration from leaf and canopy reflectance. Remote Sens. Environ. 74(2):229-239.

Ervin, E.H. and A.J. Koski. 2001. Trinexapac-ethyl increases kentucky bluegrass leaf cell density and chlorophyll concentration. HortScience 36:787789.

Ervin, E.H., C.H. Ok, B.S. Fresenburg, and J.H. Dunn. 2002. Trinexapac-ethyl restricts shoot growth and prolongs stand density of 'Meyer' zoysiagrass fairway under shade. HortScience 37:502-505.

Fitz-Rodríguez, E. and C.Y. Choi. 2002. Monitoring turfgrass quality using multispectral radiometry. Trans. Amer. Soc. Agr. Eng. 45(3):865-871.

Horst, G.L., M.C. Engelke, and W. Meyers. 1984. Assessment of visual evaluation techniques. Agron. J. 76(4):619-622.

Jacquemoud, S., S.L. Ustin, J. Verdebout, G. Schmuck, G. Andreoli, and B. Hosgood. 1996. Estimating leaf biochemistry using the PROSPECT leaf optical properties model. Remote Sens. Environ. 56(3):194-202.

Jensen, J.R. 2007. Remote sensing of the environment: An earth resource perspective. 2nd ed. Pearson Prentice Hall, Upper Saddle River, NJ.

Jiang, Y. and R. Carrow. 2007. Broadband spectral reflectance models of turfgrass species and cultivars to drought stress. Crop Sci. 47(4):1611-1618.

Jiang, H. and J. Fry. 1998. Drought responses of perennial ryegrass treated with plant growth regulators. HortScience 33:270-273.

Karcher, D.E., M.D. Richardson, J.W. Landreth, and J.H. McCalla. Jr. 2005. Recovery of bermudagrass varieties from divot injury. Appl. Turfgrass Sci. 2(1): doi: 10.1094/ATS-2005-0117-01-RS. 
Knipling, E.B. 1970. Physical and physiological basis for the reflectance of visible and near-infrared radiation from vegetation. Remote Sens. Environ. 1(3):155159.

Kowalewski, A.R., B.M. Schwartz, A.L. Grimshaw, J.N. McCrimmon, and J.M. Layton. 2014. Mowing requirement and cost to maintain bermudagrass is influenced by cultivar selection and trinexapacethyl use. Appl. Turfgrass Sci. 11(1):doi: 10.2134/ATS-2014-0019-RS.

Linde, D.T., L.J. Stowell, W. Gelernter, and K. McAuliffe. 2011. Monitoring and managing putting green firmness on golf courses. Appl. Turfgrass Sci. 8(1):doi: 10.1094/ATS-2011-0126-01-RS.

Marten, G.C. and R.F. Barnes. 1980. Prediction of energy digestibility of forages with in vitro rumen fermentation and fungal enzyme systems, p. 61-71. In: W.J. pidgen, C.C. Balch, and M. Graham (eds.). Standardization of analytical methodology for feeds. Intl. Dev. Res. Ctr., Ottawa, ON, Canada.

McCann, S.E. and B. Huang. 2007. Effects of trinexapac-ethyl foliar application on creeping bentgrass responses to combined drought and heat stress. Crop Sci. 47(5):2121-2128.

McCarty, L.B., J.S. Weinbrecht, J.E. Toler, and G.L. Miller. 2004. St. augustinegrass response to plant growth retardants. Crop Sci. 44(4):1323-1329.

McCarty, L.B., T.G. Willis, J.E. Toler, and T. Whitwell. 2011. 'TifEagle' bermudagrass response to plant growth regulators and mowing height. Agron. J. 103(4):988-994.

McCullough, P.E., H. Liu, L.B. McCarty, and J.E. Toler. 2007. Trinexapac-ethyl application regimens influence growth, quality, and performance of bermuda grass and creeping bentgrass putting greens. Crop Sci. 47(5):2138-2144.

Meinhold, V.H., R.L. Duble, R.W. Weaver, and E.C. Holt. 1973. Thatch accumulation in bermudagrass turf in relation to management. Agron. J. 65(5):833-835

Morris, K. 2000. 1995 National Kentucky bluegrass test. Prog. Rpt. NTEP 00-12. Natl. Turfgrass Evaluation Program, U.S. Dept. Agr., Agr. Res. Serv., Beltsville, MD.

Morris, K. and R. Shearman. 1998. NTEP turfgrass evaluation guidelines, p. 1-5. In: NTEP Turfgrass Evaluation Wkshp., Natl. Turfgrass Evaluation Program, Beltsville, MD.

Murphy, R. 1995. The effects of surficial vegetation cover on mineral absorption feature parameters. Intl. J. Remote Sens. $16(12): 2153-2164$

Richardson, M.D., D.E. Karcher, and L.C. Purcell. 2001. Quantifying turfgrass cover using digital image analysis. Crop Sci. 41(6):1884-1888.

Shearman, R.C. and J.B. Beard. 1975. Turfgrass wear tolerance mechanisms: III. Physiological, morphological, and anatomical characteristics associated with turfgrass wear tolerance. Agron. J. 67(2):215-218.
Tilley, J.M.A. and R.A. Terry. 1963. A twostage technique for the in vitro digestion of forage crops. Grass Forage Sci. 18(2):104111.

Trenholm, L., R. Carrow, and R. Duncan. 1999. Relationship of multispectral radiometry data to qualitative data in turfgrass research. Crop Sci. 39(3):763-769.

Trenholm, L.E., R.N. Carrow, and R.R. Duncan. 2000a. Mechanisms of wear tolerance in seashore paspalum and bermudagrass. Crop Sci. 40(5):1350-1357.

Trenholm, L., J. Cisar, and J. Unruh. 2000b. Bermudagrass for Florida lawn. 19 Oct. 2016. <http//edis.ifas.ufl.edu/ pdffiles/LH/LH00700.pdf>.

U.S. Golf Association. 2009. TruFirm: New impact measurement of golf courses and sports field surfaces. 19 Oct. 2016. <http://gsrpdf.lib.msu.edu/ticpdf.py? file $=/ 2000 \mathrm{~s} / 2009 / 090327 . \mathrm{pdf}>$

Van Soest, P.J., J.B. Robertson, and B.A. Lewis. 1991. Methods for dietary fiber, neutral detergent fiber, and nonstarch polysaccharides in relation to animal nutrition. J. Dairy Sci. 74(10):3583-3597.

Vogel, K.P., J.F. Pedersen, S.D. Masterson, and J.J. Toy. 1999. Evaluation of a filter bag system for NDF, ADF, and IVDMD forage analysis. Crop Sci. 39(1):276-279.

Xiong, X., G.E. Bell, J.B. Solie, M.W. Smith, and B. Martin. 2007. Bermudagrass seasonal responses to nitrogen fertilization and irrigation detected using optical sensing. Crop Sci. 47(4):1603-1610. 